Paideusis

\title{
Technology and Justice (George Grant)
}

\section{Howard R. Woodhouse}

Volume 3, Number 1, 1989

URI: https://id.erudit.org/iderudit/1073406ar

DOI: https://doi.org/10.7202/1073406ar

See table of contents

Publisher(s)

Canadian Philosophy of Education Society

\section{ISSN}

0838-4517 (print)

1916-0348 (digital)

Explore this journal

Cite this review

Woodhouse, H. (1989). Review of [Technology and Justice (George Grant)]. Paideusis, 3(1), 18-19. https://doi.org/10.7202/1073406ar viewed online.

https://apropos.erudit.org/en/users/policy-on-use/ 


\section{Book Reviews}

George Grant, Technology and Justice (Anansi: Toronto, 1986). 135 pages. Paperback: $\$ 8.95$

George Grant's death in September, 1988 put an end to his reflections upon technology, modernity, and the exclusion of Platonism and even Christianity from the modern world. As a Canadian philosopher, Grant raised fundamental questions about these matters that are peculiarly our own. Nevertheless, he did so in ways that evoke early traditions of Western thought whose language and ontology may seem quite alien to the modern reader.

Technology and Justice, Grant's last book, is a collection of six essays on technology, faith and the multiversity, Nietzsche, research in the humanities, euthanasia, and abortion. They are all in a fundamental sense educational but it is upon 'Faith and the Multiversity' that I shall concentrate, since it is the book's central essay ${ }^{1}$ and most clearly concerned with formal education.

The question that Grant asks is this: how is it possible for those who have faith to live in the multiversity where the dominant paradigm of knowledge, namely modern science, separates the process of knowing from that of loving? If, at the core of the modern university, there is a radical separation between intelligence and love, what meaning does Simone Weil's conception of faith as the experience of intelligence enlightened by love have (p. 38)? Clearly, the reductionist methods of science, its concern for objective knowledge, and instrumentalist urge to dominate nature exclude the possibility of faith in Weil's sense. It is these aspects of science and their impact upon the university that leads Grant to refer to that institution as fundamentally divided, a multi-versity (p. 37). ${ }^{2}$

Grant is deeply concerned about all of this because he takes Weil to have understood the foundations of faith most clearly. Like her, he believes the unity of intelligence/reason and love to underlie the most profound of human experiences and, in order to illustrate their fundamental unity, appeals to Plato's Republic, where the search for knowledge is identified with the process of loving (pp. 72-73).

Grant suggests two rays of hope that may prevent faith from being extinguished from the multiversity. First, students and faculty may engage in reflection that enables them to recall that the true, the good, and the beautiful are one. Unfortunately, such Platonic reflection is normally killed among students by the paradigm of modern science (p. 70). Second, western Christianity and modern science have both shared a desire to dominate the world. The arrogance of this position may be brought home to some in the multiversity who come to appreciate the emptiness at the core of modern science (p. 64 and pp. 76-77).

Grant's hopes for a disenchantment with the paradigm of modern science and a turning towards faith appear forlorn. He was well aware of the power of the scientific paradigm but serious in his search for an alternative to the modern belief that human beings are distinctively free (pp. 74-75). He could not succumb to the tenets of liberalism that we realise our freedom by making the world as we want it, largely by means of modern science (pp. 57-61 and p. 65). ${ }^{3}$ 
Was Grant correct to be so skeptical of modem thought? Two reasons suggest that he was not.

First, there are other kinds of reason than instrumental reason in the modern world. The work of the critical theorists, and particularly that of Jurgen Habermas, has shown that embedded in the Enlightenment project were also communicative and emancipatory reason based on shared norms and human needs that make possible non-instrumental views of human freedom. To the extent that the instrumental reason of modem science suppresses these shared norms and needs, it is to be criticised for hindering the advent of a more open and sharing society. Rather than turning back to Plato, the critical theorists articulate a critique of technology and science from within the assumptions of modernity. ${ }^{4}$

Second, a dialectical search for truth of this kind that poses human needs and their negation as the foundation of its critique surely has its roots in the Socratic method. Given the possibility of shared norms and expressed needs outside the paradigm of instrumental reason, the pursuit of truth need not be distinct from the search for the good and the beautiful. In this way the "modern experiment" is not as different from the Socratic enterprise as Grant supposes (p. 43), provided that it is not confined within instrumental reason.

Grant was aware that he shared a common ground with those of us standing within modernity but skeptical of technology and science, and particularly with those of us critical of U.S. imperialism. But he charted a different course that led him back to the Ancients in his quest for unity. His voice will be missed.

Howard R. Woodhouse, University of Saskatchewan

\section{Notes}

'William Christian, "Champion of Intellect in the Age of Technology," The Globe and Mail, September 30, 1988.

${ }^{2}$ George Grant, "The University Curriculum," Technology and Empire, (Anansi Press, Toronto, 1969).

${ }^{3}$ This was forcefully expressed in Grant's "In Defence of North America," ibid.

4Jurgen Habermas, "Technology and Science as Ideology," Toward a Rational Society (Beacon Press, Boston, 1970). 